\title{
NEW DIMENSIONS OF THE IMPORTANCE OF A CREATIVE WORK ENVIRONMENT AND ITS IMPACT ON THE MANAGEMENT OF CONTEMPORARY ORGANIZATIONS
}

\author{
Svetlana Vukotić \\ Faculty of Applied Management, Economics and Finance in Belgrade, \\ University Business Academy in Novi Sad, Republic of Serbia \\ Darjan Karabašević \\ Faculty of Applied Management, Economics and Finance in Belgrade, \\ University Business Academy in Novi Sad, Republic of Serbia \\ Vuk Mirčetić* \\ Faculty of Applied Management, Economics and Finance in Belgrade, \\ University Business Academy in Novi Sad, Republic of Serbia

\section{Mlađan Maksimović} \\ Faculty of Applied Management, Economics and Finance in Belgrade, \\ University Business Academy in Novi Sad, Republic of Serbia
}

\begin{abstract}
A creative work environment has been attracting researchers' attention in recent decades. Apart from the academic public, the professional public also shows an interest in this concept. It is already becoming a necessity nowadays. Because competition has intensified, the need to be different in the business process has been reinforced. Uniqueness is most pronounced in creativity. Not very often can creativity repeat itself in the same way. Modern management practice recommends that the inventiveness and creativity of all employees who represent partners in a creative work environment should be taken into account. This paper is aimed at analyzing the importance of generating a creative work environment and the implications for management in organizations. In addition to creativity, a team concept has been introduced into a creative work environment, as well as multitasking and the creative competence of employees as regards job designing. Leadership and communication in a creative work environment, and motivation and a reward for performance, are also discussed. A creative work environment is a very layered and complex concept with a challenging and stimulating effect on future research. A creative work environment is an essential prerequisite for achieving and maintaining a competitive advantage, while
\end{abstract}

*vuk.mircetic@mef.edu.rs 
114 | NEW DIMENSIONS OF THE IMPORTANCE OF A CREATIVE WORK ENVIRONMENT AND ITS IMPACT ON THE MANAGEMENT OF CONTEMPORARY ORGANIZATIONS

enabling the organization to follow its mission and vision.

Key words: creativity, creative work environment, team work, job design, leadership, motivation, innovation

JEL classification: M54, L20, O31

\section{NOVE DIMENZIJE ZNAČAJA KREATIVNE RADNE SREDINE I NJEN UTICAJ NA UPRAVLJANJE SAVREMENIM ORGANIZACIJAMA}

Sažetak: Kreativna radna sredina zaokuplja pažnju istraživača poslednjih decenija. Pored akademskih krugova, i stručna javnost pokazuje interes za ovaj koncept. Sada to već postaje i neminovnost, jer je konkurencija intenzivirana, pa je prema tome pojačana i potreba da se bude drugačiji u procesu poslovanja. Posebnost je najviše izražena kod kreativnosti. Kreativnost se veoma često ne može ponoviti na isti način. U praksi savremenog menadžmenta se preporučuje uvažavanje inventivnosti i kreativnosti svih zaposlenih koji predstavljaju partnere u kreativnoj radnoj sredini. Cilj ovog rada je analiziranje značaja kreativne radne sredine $i$ implikacija na upravljanje $u$ organizacijama. Pored kreativnosti, predstavljen je i timski koncept u kreativnoj radnoj sredini, kao i multitasking i kreativne kompetencije zaposlenih u svetlu dizajna radnih mesta. Takođe, u radu su prikazani liderstvo i komunikacija u kreativnoj radnoj sredini $i$ motivacija i nagrađivanje prema performansama. Kreativna radna sredina je veoma slojevit i kompleksan koncept koji izazovno i podsticajno deluje na buduća istraživanja. Kreativna radna sredina je bitan preduslov za postizanje i zadržavanje konkurentske prednosti, pritom omogućava organizaciji da prati svoju misiju i viziju.

Ključne reči: kreativnost, kreativna radna sredina, timski rad, dizajn radnog mesta, liderstvo, motivacija, inovacija

\section{INTRODUCTION}

Firstly, a person is creative; products, processes, even an environment can be creative. A creative work environment implies innovation, the freedom of thought and the exchange of ideas. Milošević (2004, p.153) highlights the fact that, since the 1960s, "work creativity" and the creativity and inventiveness of all employees have been growing in importance, which further implies the success of organizations on the market. Undoubtedly, the capability of organizational innovation plays a crucial role in determining organizational success, as well as achieving and retaining a competitive advantage (Cascio and Aguinis, 2019). Kremer, Villamor and Aguinis (2019) point out the fact that innovative leaders are, in fact, the agents of changes who promote the 
manifestation of new ideas in the context of a work environment, creating a supportive climate for creativity and innovative process management.

Different factors influence creativity, but people are assumed to be born creative. However, it sometimes occurs that creativity throughout life gradually fades away, becomes completely lost, or further develops. Creativity is the ability to create something new with an imaginative skill, be it a new solution to a problem, a new method or design, or a new art object or form. This term usually refers to the richness of ideas and the originality of thinking, as well the practicality of work (Vidanović, 2006, p. 29).

Creativity depends on two types of factors (Arizanović, 2007):

- Micro-factors - operating in organizations, and

- Macro-factors - originating from a social environment.

The main micro-factors are a motivation for creative work, the personnel structure, and the quality of the innovation potential, the style of leading the organization, the application of modern entrepreneurship techniques, and the stimulation of creative thinking. The macroclimate creativity of a country consists of a whole set of the political and economic significance of its location. First, the level of democracy is very important, as well as the freedom of thought, the stability of the legislative system, the rule of law and the quality of the infrastructure. Society best encourages innovation and creativity when it allows and even stimulates different thinking.

The focus of the analysis in this paper is on micro-factors. The common denominator with a macroclimate is undoubtedly the freedom of thought, or the level of democracy, and even a difference of opinion. Companies have to influence more significant employee interaction, the tolerance of failure, a freedom to achieve goals, and creativity rewarding (Marković, Prodanović and Mutibarić, 2012).

Hameed, Ashraf, Ashraf, Saeed and Khushbkhat (2014) underline the fact that significant importance lies in the redesigning of jobs for the purpose of motivating employees, so it needs to be implemented in creative work environments.

According to Markevičiūte and Jucevičius (2013), creativity is often measured in terms of creative results or the conditions needed to produce such results, not so much in terms of creative inputs. These authors also emphasize the fact that a creative work environment is the connector between a creative competence and the creation of organizational value, as it aims to manage organizational change, develop new ideas and form new attitudes towards understanding competitive organizational advantages. Modern business is based on speed, quality, 
116 | NEW DIMENSIONS OF THE IMPORTANCE OF A CREATIVE WORK ENVIRONMENT AND ITS IMPACT ON THE MANAGEMENT OF CONTEMPORARY ORGANIZATIONS

flexibility, connectivity and building a critical mass of the capital and production/service potentials. Change is fast, complex and unpredictable, so managing a modern business requires a change in mind regarding how to do business in the new economy. This new style of business requires a team approach and developing team members' competences (Aničić, Zakić, Vukotić and Subić, 2016).

Focusing on employees' interests and developing their affinities and preferences within their labor organizations support the efforts of those who recognize organizational culture as opposed to thwarting the efforts of those ignoring it. In this regard, a creative work environment is one of the key factors that influence employees' perception of the organization, their motivation and effective work. In that manner, it becomes a work environment that leaves room for creative work.

Modern conditions impose new characteristics on organizations as business entities, both in terms of their operations and in terms of management. Flexibility rather than stability is emphasized, and dynamic principles replace deterministic ones. These assumptions imply that work should be so conceptualized to comprise two central segments: creativity, as the starting point, and a creative work environment, as the factor that influences the success of the business done by an organization. In addition to these main sections, the paper has the introductory and conclusive considerations. There are benefits of this paper which the professional and scientific public may be interested in, seeking to broaden cognitive discourses on this topic, or striving for "the practical improvement of the business." Therefore, the paper is structured as follows: in the second part of the paper, creativity is presented as a management segment and a creative working climate; in the third part, a creative work environment is explained, and finally, the conclusion is drawn.

\section{CREATIVITY AS A SEGMENT OF MANAGEMENT AND A CREATIVE WORKING CLIMATE}

Creativity can be defined as the ability to create new and unusual ideas. Creativity is the ability to solve complex problems and create new knowledge. Business creativity is not only an original idea, but it is also an appropriate and applicable idea (Amabile, 1998). In fact, it is the art of thinking, reacting, and acting in a highly innovative, original, and risky way. As a rule, risk accompanies what is new, unknown, or unexplored. Apart from creating new ideas, creativity also uniquely combines old (already known) ideas and is a prerequisite for innovation (Rikalović, 2010). Therefore, it is only through the transformation of creative ideas into useful products and services with a 
practical application that innovation is created. According to Bessant and Tidd (2011, p. 339), innovation is generally not a single act, but a multiplayer act.

Support from leaders in fostering a work environment in an organization supportive of creativity and innovation is of vital importance. By promoting a climate for creativity and innovation in which employees are encouraged to make proposals for solutions, express their opinions and make suggestions, leaders also have an opportunity to implement the proposed ideas and support the employees in that manner. Thus, when the focus is on the lessons learnt rather than the mistakes made, employees become aware of the fact that their superiors are accessible, interested in contributing to others and open up to new ideas and suggestions (Zuraik and Kelly, 2019; Teo, 2005).

Accordingly, as a trait of management, creativity should not be the exclusive "right" of top management. On the contrary, Komazec and Petrović-Lazarević (2007, p. 284) emphasize the fact that the task of all employees is to foster a creative climate. In order to improve overall business and, therefore, organizational culture as a prerequisite and a result, creativity becomes an essential segment of management and the basis for the implementation of the TCM model (Total Creativity Management). In contrast to the TQM (Total Quality Management) model, whose application leads to increased product performance, the TCM system enhances creativity.

The use of human resources is not impaired, but the idea to find the ways to make use of employees' true values is not wrong as long as it does not imply their exploitation (Vukotić, Milovanović, Bugarčić and Perišić, 2015). There are many techniques to encourage creativity, (e.g. the Delphi method and SWOT analysis), but only one is often given particular importance. The decisionmaking process is a creative meeting of a selected group of experts, during which their opinions and views are collected. All ideas are welcome and participants are asked to freely "fantasize" within a set problem or task. It is also a way to generate a large number of ideas from a group of people in a short time. A strategic brainstorming exercise is graphically presented in Figure 1.

The absence of creativity is caused by the environment and the situations in which people live and work. In these situations, much more is required to replace consent with creativity and conformity with non-conformity. Table 1 shows the circumstances and environment that encourage or relativize creativity. 


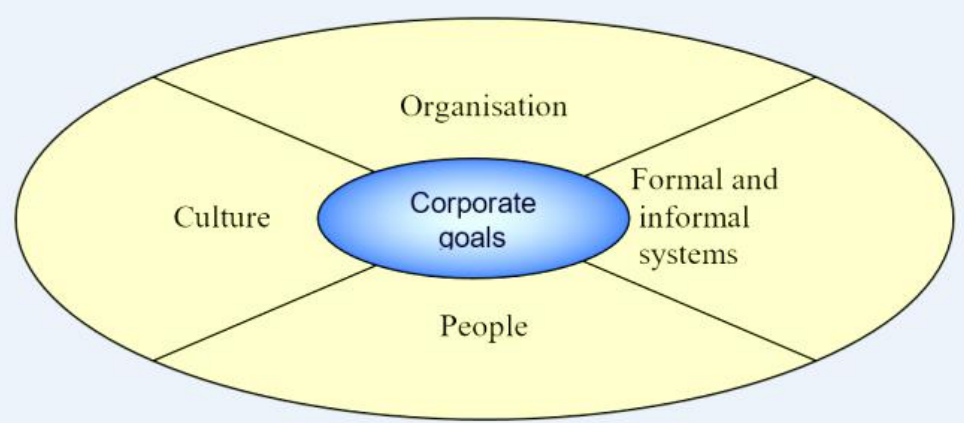

Managers write a corporate goal in the centre and brainstorm changes that need to take place in each of the four areas, one area at a time

Figure 1. A strategic brainstorming exercise

Note. Retrived from Torrington D., Hall L., and Taylor S. (2004). Human Resource Management. Belgrade: Data status.

Table 1

The circumstances and the ambience that stimulate/limit creativity

\begin{tabular}{cc}
\hline $\begin{array}{c}\text { The circumstances and the } \\
\text { ambience that stimulate creativity }\end{array}$ & $\begin{array}{c}\text { The circumstances and the ambience } \\
\text { that limit creativity }\end{array}$ \\
\hline A stormy progression & Bureaucracy \\
Continuous change & Uniformity requirements \\
"Whirlpools" in the setting & Static hierarchical structures \\
Increasing conflicts & Programming \\
Complex technology & Model standardization \\
Increased needs & Excessive reliance on experience and \\
Complex decisions & logic \\
Unforeseen events & Compliance with strict rules \\
Geographic and market changes & Fear of change \\
Innovation and entrepreneurship & Fear of trouble \\
\hline
\end{tabular}

Note. Adapted from Manager Dolphin, number 15.

Creativity is also a form of reasoning in a new way. It is primarily an innate human trait, as well as a product of the environmental impact of humans. 


\section{A CREATIVE WORK ENVIRONMENT}

Contemporary business trends have led to the reallocation of roles from management to all employees. No market success is possible without employees' creativity and inventiveness. Hence, in a creative work environment, changes are introduced in a horizontal instead of vertical connection between certain individual organizational parts. The holistic model rests on a horizontal structure, in which all parts are free, and in which responsibility and power are horizontally distributed. In this model, there are no hierarchical relationships, which is the fundamental feature of traditional systems (Torrington, Hall and Taylor, 2004).

\subsection{A TEAM CONCEPT IN A CREATIVE WORK ENVIRONMENT}

In the change process, there is a reorientation from an organization's short-term to its long-term interests and goals. Employees need to learn how to use new technologies and knowledge or how to effectively work in teams.

Creativity and innovation are frequently used to represent different aspects of the innovation process. Baruah and Paulus (2019) point out the fact that organizations are increasingly dependent on teamwork, which has also led to a shift in the focus from individual to team creativity and innovation. Teamwork and team creativity are becoming a significant concept in contemporary organizations striving for organizational goals and activities (Sawyer, 2017; Baruah and Paulus, 2019).

The further features of the increasing importance of a creative work environment are stated in teamwork. Specifically, organizations introduce selfregulatory teams and the so-called quality teams or quality cycles.

Self-regulatory or self-managing teams are a relatively new type of a team concept. The traditional labor relationships based on a stable hierarchy have been replaced with the relationships of tolerance, equality and a creative pursuit of ordinary affairs, as well as responsive challenges. Such a constellation of relationships does not require managers to control the work of the employees because self-managing teams have the highest degree of autonomy and control themselves. An overview of the activities of self-managed teams is given in Table 2. 
120 | NEW DIMENSIONS OF THE IMPORTANCE OF A CREATIVE WORK ENVIRONMENT AND ITS IMPACT ON THE MANAGEMENT OF CONTEMPORARY ORGANIZATIONS

Table 2

The ten activities of self-managing teams

\begin{tabular}{cc}
\hline Authorized & $\begin{array}{c}\text { Prepare budgets and coordinate work } \\
\text { Order material, maintain inventory, } \\
\text { Plan, control, develop work processes }\end{array}$ \\
Form team goals & $\begin{array}{c}\text { and contact suppliers } \\
\text { Provide the necessary training } \\
\text { Organize replacements or discipline } \\
\text { Inspect own work }\end{array}$ \\
Schedule and performance review & Take responsibility for quality \\
\hline
\end{tabular}

Note. Retrived from Evans J., R., and Lindsay W., M. (2002). The Management and Control Quality. USA, Ohio: South Western.

For the teams called quality cycles, the enduring goal is synergism and a new quality throughout the organization. If the result of teamwork is better than the sum with which individuals entered the team and if it can be expressed by the simple formula $2+2=5$, then it is considered that there is synergism in that team. In contrast, antagonism exists if the result of teamwork is less than the sum with which individuals entered and contributed to the team and if it can be expressed by the formula $2+2=3$. However, this is not even the most negative thing that may happen, because in situations where team members quarrel and disperse without any results, $2+2=0$.

The continuous training of team employees, either individually or externally, could be said to be one of the characteristics of a creative work environment. All this needs to be encouraged by employees, and employees with adequate competences or expertise should be able to fulfil the essential prerogatives in the current circumstances.

\subsection{MULTITASKING AND EMPLOYEES' CREATIVE COMPETENCES WITH REGARD TO JOB DESIGN}

Competent employees are a vital resource for any organization. At the same time, every organization strives for their employees to have more and more competences. An employee should be able to cover a wide range of jobs. An individual employee who can respond to multitasking will be able to show their work values in the right way and achieve performance for the company (Vukotić, Zakić, Aničić and Vuković, 2014). Competences are a set of skills, knowledge, and behavior, i.e. the motives, characteristics and desired behavior of an individual for a particular job or level. Competences can be said to be a prerequisite for success. Competences enable an individual to achieve their personal and professional goals and help him/her to find suitable employment (Karabašević, Stanujkić, Urošević and Maksimović, 2015; Karabašević, 
Zavadskas, Turskis and Stanujkić, 2016; Urošević, Karabašević, Stanujkić and Maksimović, 2017).

Accordingly, it implies the confirmation of the more common position that the description and specification of the workplace are archaic forms, since the overall multidisciplinary nature of the workforce, i.e. employees have become much more mobile and have a wide range of knowledge and skills. Ultimately, this is in line with knowledge management, which does not call into question that work should be completed, but one should not restrain one's creativity and set strict rules and formalize all the ways that will lead to a result and a successful final product. As far as a job description is concerned, Fisher, Schoenfeldt and Shaw (1999) argued that it was appropriate for those repetitive jobs only. It is defined as the static category that ignores job dynamism and Cascio (1991) even designates it as sterile. The objections they make are also attributable to the fact that they are given bureaucratic qualifications and seals and that this establishment is becoming counterproductive. Peters (1989) refers to them as the imperatives that require managers and employees to cross insurmountable boundaries.

On the other hand, Stone (2002) emphasizes the fact that the Japanese generalize their training and promote flexibility in employee allocation. In Japan, moving from one workplace to another is not only an acceptable procedure, but it goes without saying. Following a further chronology, there was an increase in workload, i.e. job enrichment, which was a reality in learning organizations. Stone (2002, p. 153) particularly emphasizes the socio-technical enrichment aimed at integrating people with technology. Until recently, job rotation was a specific feature of Japan's organizational structure. However, this does not mean that it cannot be applied in other countries as well. Szabó, Slavic and Berber (2019) investigate the impact of the type of training on employee performance. Moreover, coaching has an impact on organizational behavior, as well as performance (Raza, Ali, Ahmed and Ahmad, 2018).

Therefore, job descriptions are only general guides, not rigid and limited creations, which Townley (1994) calls the first level of employee control, which therefore becomes predictable and calculated. According to Urošević, Stanujkić and Karabašević (2018, p. 24), however, job analysis needs to be updated and performed so as to verify the competences of employees. The role of job analysis in contemporary organizations is significant and complex because, in the case of a lack of adequate or specific competences, training is needed to adapt an individual to the requirements of the job position. 
122 | NEW DIMENSIONS OF THE IMPORTANCE OF A CREATIVE WORK ENVIRONMENT AND ITS IMPACT ON THE MANAGEMENT OF CONTEMPORARY ORGANIZATIONS

\subsection{LEADERSHIP AND COMMUNICATION IN A CREATIVE WORK ENVIRONMENT}

Managers' primary duties are to work with people, strive for a more consensual attitude, for relationships to be harmonious, and for a high cooperation level. Managerial duties should contribute as much as possible to the company and its progress. In any case, contemporary organization operates in pluralistic social structures. Therefore, it must be directed by the modern management that enjoys authority, not commanding but inspiring (Icak, 2005). Such a climate ensures employees security, autonomy, and intellectual stimulation necessary for creativity. Simultaneously, the influence of transformational leaders will inspire and increase employees' commitment to achieving their goals (Stevanović, 2014, pp. 175-176). Hence, transformational leadership has been attracting public attention for some time and has been gaining in popularity. Thus, for example, Kim, Park and Kim, (2019) conclude that transformational leadership enhances team creativity, giving employees the psychological security that originates from group creativity and thus enhances creativity at the individual level.

As firms increasingly rely on 'teams' to enhance innovation, however, we need to take into account the factors that affect team-level creativity. To address this issue, we attempt to find the underlying mechanisms that drive the relationship between transformational leadership and team-level creativity. Based on a group creativity model, we argue that transformational leadership improves team creativity through an employee's psychological safety and subsequently facilitates their individual-level creativity.

Leadership rests on the four sets of activities, these being: interpretation, design, mobilization, and inspiration. Interpretation is the leadership activity that involves scanning and accurate interpretation of an environment. Design is the activity related to the creation of a vision and the establishment of a strategy for the translation of the vision into an action. Mobilization involves a set of activities intended to guide the behavior of the members of an organization towards achieving its goals. Inspiration is an activity intended to create a desirable climate for the free expression of creativity and talent.

Leadership is an essential dimension of the organization and a prerequisite for the ongoing competitive advantage of the organization. Therefore, leadership as a phenomenon can be characterized through the dynamic that: modern leaders do not create followers, but new leaders instead (Peters, 1989). The leadership provided by the organization's management and employee behavior go together into the implementation process. Leaders' tasks are linked with the fostering of the culture of a company that needs to succeed and leadership is an essential 
factor in the shaping of organizational culture, and therefore a critical factor in changing it. Much of the research study by Shannahan, Bush and Shannahan (2013) shows that, e.g. sales are more successful when leaders create a company culture characterized by open communication between its employees and the management. In this way, employees have the right to express their opinions and ideas about the sales strategy and implementation activities. This type of leadership creates a climate where management and employees have complete trust in each other. Furthermore, trust is a factor that influences the manner in which a leader's/manager's personality will be profiled. As a necessary precondition for certain perceptions, i.e. certain actions needed for an excellent performance, trust can be viewed in the following context (Stamatović, Milivojević and Vukotić, 2008):

- experience-authentic communication,

- the feeling of a personalized support,

- support in collaboration and teamwork, and

- taking thoughtful risks.

Organizational communication involves the existence and use of a predesigned information transfer system which can transmit information to a large number of people inside or outside the organization. Thus, not all communication in an organization is organizational communication, but it represents a thoughtful management effort only (Robbins and Judge, 2009, pp. 368-369). The formal organizational structure mostly conditions the basis of organizational communication, i.e. the formal arrangement of labor relationships, the lines of communication that give the members of an organization a certain official status.

Communication effectiveness is of utmost importance because communication is the condition for directing and influencing employees in order for them to achieve company interests, implement change, and generate good ideas. It is not difficult to conclude that failure to communicate can be very costly.

\subsection{MOTIVATION AND PERFORMANCE-BASED REWARDING}

Organizations achieve their goals in such a way that their managers and employees achieve performance. Achieving performance depends on several key factors: employees' ability to complete tasks, chances to achieve their performance, and employee motivation. Urosević, Karabašević, Maksimović and Stanujkić (2016) emphasize the fact that many factors influence employee performance. In this regard, they specifically emphasize the importance of building a motivational system in order to increase employee performance and increase the competitive ability of the organization. The ability depends on the level of education and the competence of the workers and can be enhanced by SCHOOL OF BUSINESS, 2/2019, 113-129 
124 | NEW DIMENSIONS OF THE IMPORTANCE OF A CREATIVE WORK ENVIRONMENT AND ITS IMPACT ON THE MANAGEMENT OF CONTEMPORARY ORGANIZATIONS

on-the-job training. Occasionally, the organizational structure of a company provides opportunities for employees. However, an employee may be qualified for performance and given an opportunity, but nothing will be achieved if he/she is not motivated (Mirčetić and Vukotić, 2017).

What is even more remarkable about the research study conducted by Sherif, Nimran and Prasetya (2014) is the fact that the employees satisfied with their salaries are happy employees working in a motivated and timely manner in fulfilling their obligations. On the other hand, if the same task already given to one employee is given to another employee without offering the latter a higher salary, he/she will be less motivated to accomplish it. Even though this indicator is extremely logical, it still indicates that, sometimes, a promise given to an employee that he/she will be given a possibility of earning a higher salary can be a more significant motivating factor than when the same is nonexistent at all- without any further assumptions regarding whether the promise will be fulfilled or not.

Accordingly, what Milivojević (2009, p. 97) argues is that there is no normative model of work motivation that would apply to all individuals in all situations; it is also true, however, that the aspects related to the content and meaning of work have indeed been underestimated and neglected for a long time. Of course, there are no readymade formulas for success today, but it is always important to look at negative effects in addition to positive effects.

In developed countries, rewards are readily accepted for an individual's contribution to the organization's success. Many companies seek to focus their employees' attention on the company goals by linking goal achievement with employee rewards. In this way, they encourage:

- the performance of an individual, team or business unit to make a remuneration initiative dependent on the specific performance of the employee or the workgroup,

- the control of compensation costs by determining the number of risky payments if business units, teams or individuals fail to meet their goals, and

- competition in remuneration.

Performance-based rewarding will be the most effective if aligned with organizational culture and the managerial style (Stone, 2002).

In terms of motivation theories, we can say that they may serve as the starting point for managers to motivate people in different ways. First, they identify and understand employees' needs and capabilities and also articulate the organization's vision. Furthermore, by applying motivating techniques, 
managers give a support to the employees' efforts to bring the company's vision to reality. They also help clarify goals and performance expectations.

The organizations that follow contemporary trends and build a creative work environment will incorporate employee motivation as a postulate, also simultaneously paying attention to performance and compensation.

\section{CONCLUSION}

A creative work environment is gaining in importance in the current circumstances, where the only change is constant. The multilayered nature of this concept is based on changes in the organization, communication, and motivation. Increasingly, priority is given to horizontal connectivity compared to vertical connectivity between individual organizational units. Efforts are made to encourage communication at all levels, simultaneously rewarding employees for their performance and motivation.

In creative work environments, the focus is on the company's long-term interests and ambitions. Employees are encouraged to improve because, if an individual in the organization is building a career, the entire organization will benefit from it. The team concept is acknowledged and particular importance is attached to the teams that emphasize quality, confidence, and creativity.

There is a lack of rigidity in designing jobs. It is an imperative nowadays, implying that multitasking is increasingly present. Therefore, "if everyone does everything", then condensed and formalized job descriptions and specifications cannot be expected to successfully work in the future. A correct functionality may be possible, but creativity will diminish.

The existence of leaders who inspire and encourage their employees is the hallmark of a creative work environment. The participation of all stakeholders in managerial decisions and new management practices helps generate ideas and contribute to creativity and inventiveness. Rotation, which involves changing jobs from time to time, as well as expanding jobs or enriching work, are all the modalities that should exist in a creative work environment.

Further research in this area should, of course, include training or training for employees in work environments. We live in a time marked by the lifelong learning concept; accordingly, training is becoming inevitable for all those who strive for creativity. In addition, much attention should be paid to corporate culture when considering a creative work environment. All in all, this is yet another confirmation of how inspiring this topic is. 
126 | NEW DIMENSIONS OF THE IMPORTANCE OF A CREATIVE WORK ENVIRONMENT AND ITS IMPACT ON THE MANAGEMENT OF CONTEMPORARY ORGANIZATIONS

\section{REFERENCES}

Amabile, T.(1998). How to Kill Creativity. Harvard Business Review, 76(5), 76-87.

Aničić, J., Zakić, N., Vukotić, S., \& Subić, J. (2016).Clustering as an opportunity for internationalization of the SME sector in Serbia. Journal of Balkan and Near Eastern Studies, 18(5), 506-524.

Arizanović, G.(2007). Kreativnost i menadžment. Aleksandrovac: Arizan.

Baruah, J., \& Paulus, P. B. (2019). CollaborativeCreativityandInnovation in Education. In Creativity Under Duress in Education? (pp, 155-177). Springer.

Bessant, J., \& Tidd, J. (2011). Innovation and Entrepreneurship. Chichester: John Wiley and Sons.

Cascio, W. (1991). Applied Psihology in Personnel Management. 4th edn, NY: Prentice-Hall Englewood Cliffs.

Cascio, W. F., \&Aguinis, H. (2018). Applied Psychology in Talent Management. London: SAGE Publications.

Evans J. R., \& Lindsay W. M. (2002).The Managementand Control Quality. USA, Ohio: SouthWestern.

Fisher, C. D., Schoenfeldt, L. F., \& Shaw, J. B. (1999). Human Resource Management. 4th edn, Boston: Houghton Mifflin.

Hameed, A., Ashraf, R., M., Ashraf, R., Saeed, M., \& Khushbkhat, K. (2014). Impact of job redesign on employee motivation: A case study of Bahawalnagar Pakistan. International Journal of Research in Business and Technology, 4(1), 378-384.

Ikač, N. (2006). Menadžment ljudskih resursa. Novi Sad: Fakultet tehničkih nauka.

Karabašević, D., Stanujkić, D., Urošević, S., \& Maksimović, M. (2015). Selection of candidates in the mining industry based on the application of the SWARA and the MULTIMOORA methods. Acta Montanistica Slovaca, 20(2), 116-124.

Karabašević, D., Zavadskas, E. K., Turskis, Z., \& Stanujkić, D. (2016). The framework for the selection of personnel based on the SWARA and ARAS methods under uncertainties. Informatica, 27(1), 49-65. 
Kim, B. J., Park, S., \& Kim, T. H. (2019). The effect of transformational leadership on team creativity: Sequential mediating effect of employee's psychological safety and creativity. Asian Journal of Technology Innovation, 27(1), 90-107.

Komazec, G., \& Petrović-Lazarević, S. (2007). Upravljanje razvojem preduzé́a. Beograd: Megatrend univerzitet.

Kremer, H., Villamor, I., \& Aguinis, H. (2019). Innovation leadership: Bestpractice recommendations for promoting employee creativity, voice, and knowledge sharing. Business Horizons, 62(1), 65-74.

Manager Dolphin: Menadžer Delfin, mesečni bilten praktičnih i primenjivih saveta iz menadžmenta] (1997). broj 15.

Markevičiūte, I., \& Jucevičius, G. (2013). The Role of Creativity in Organizational Value creation: Creative Competences in Different Organizational Contexts. Ekonomika ir vadyba: aktualijos ir perspetyvos, 2(30), 44-55.

Marković, J., Prodanović, R., \& Mutibarić, J.(2012). Kreativnost i inovativnost u preduzetništvu. Ekonomija: teorija i praksa, 5(3), 47-59.

Milivojević, T. (2009). Motivacija za rad-teorije i strategije. Beograd: Filip Višnjić.

Milošević, B.(2004). Transformacija organizacija rada u procesima globalizacije: uticaj novoliberalne ideologije. Sociologija, 46(2), 143166.

Mirčetić, V., \& Vukotić, S. (2017). Sistemi nagrađivanja zaposlenih: pozitivni i negativni efekti. U: Inovacijama do održivog razvoja (312-319). Beograd: Fakultet za primenjeni menadžment, ekonomiju i finansije, Beograd.

Peters, T. (1989). Thriving on Chaos. London: Pan Books.

Raza, B., Ali, M., Ahmed, S., \& Ahmad, J. (2018). Impact of managerial coaching on organizational citizenship behavior: The mediation and moderation model. International Journal of OrganizationalLeadership, 7, $27-46$.

Rikalović, G. (2010). Razvojna i ekonomska politika i kreativni kapital. Škola biznisa, 2, 26-32.

Robbins, P. S., \& Judge, A., T. (2009). Organizacijsko ponašanje. Zagreb: Mate doo. 
128 | NEW DIMENSIONS OF THE IMPORTANCE OF A CREATIVE WORK ENVIRONMENT AND ITS IMPACT ON THE MANAGEMENT OF CONTEMPORARY ORGANIZATIONS

Sawyer, K. (2017). Groupgenius: The creativepower of collaboration. New York: Basic Books.

Szabó, S., Slavić, A., \& Berber, N. (2019). Coaching and its effects on individual and organizational performances in Central and Eastern Europe. Anali Ekonomskog fakulteta u Subotici, (41), 67-80.

Shannahan, K. L., Bush, A. J., \& Shannahan, R. J. (2013). Are your sales people coachable? How sales person coachability, trait competitiveness, and transformational leadership enhance sales performance. Journal of the Academy of Marketing Science, 41(1), 40-54.

Sherif, M., Z., Nimran, U., \& Prasetya, A. (2014). The Role of Motivation in Human Resources Management: The Importance of Motivation Factors among Future Business Professionals in Libya. IOSR Journal of Business and Management, 16(8), 27-36.

Stamatović, M., Milivojević, T., \&Vukotić, S. (2008). Uloga poverenja u bankarskim transakcijama. U: Tržište bankarskih proizvoda $i$ usluga $u$ Srbiji (pp. 203-226). Beograd.

Stevanović, A. (2014). Transformaciono liderstvo kao preduslov organizacionih inovacija u turbulentnim socio-ekonomskim okolnostima. Škola biznisa, 2, 170-187.

Stone, R. J. (2002). Human Resource Management. Australia, Melbourne: John Wiley\&Sons.

Teo, T. S. H. (2005). Meeting the challenges of knowledge management at the Housing and Development Board. Decision Support Systems, 41(1), 147159.

Torrington D., Hall L., \& Taylor S. (2004). Menadžment ljudskih resursa. Beograd: Data status.

Townley, B. (1994). Reframing Human Resource Management-Power, Ethics and the Subject of Work. London: Sage.

Urošević, S., Stanujkić, D., \& Karabašević, D.(2018). Trendovi u menadžmentu ljudskih resursa - savremeni pristup izboru kadrova. Bor: Univerzitet $\mathrm{u}$ Beogradu, Tehnički fakultet u Boru.

Urošević, S., Karabašević, D., Maksimović, M., \& Stanujkić, D. (2016). Impact of demographic factors on motivation and satisfaction of employees in the leather and footwear industry. Tekstilna industrija, 64(3), 45-55. 
Urošević, S., Karabašević, D., Stanujkić, D., \& Maksimović, M. (2017). An Approach to Personnel Selection in the Tourism Industry Based on the SWARA and the WASPAS Methods. Economic Computation \& Economic Cybernetics Studies \& Research, 51(1), 85-88.

Vidanović, I. (2006). Rečnik socijalnog rada. Beograd: Asocijacija CSR Srbije.

Vukotić, S., Milovanović, M., Bugarčić, M., \& Perišić, J. (2015). Faktori koji utiču na radnu efektivnost ljudskih resursa u organizacijama. U: Zbornik radova trećeg naučno-stručnog skupa sa međunarodnim učešćem, "Politehnika". Beograd.

Vukotić, S., Zakić, N., Aničić, J., \& Vuković, D. (2014). Knowledge, education and innovation in the function of professional and economic development in Serbia. The Privolzhsky scientific journal, 1(29), 172-181.

Zuraik, A., \& Kelly, L. (2019). The role of CEO transformational leadership and innovation climate in exploration and exploitation. European Journal of Innovation Management, 22(1), 84-104.

Delivered: 10.10.2019.

Accepted: 27.11.2019. 